\title{
A new method of disinfection of the flexible fibrebronchoscope
}

\author{
ANGEL GARCIA DE CABO, PEDRO L. MARTINEZ LARRIBA, JOSE CHECA PINILLA, AND \\ FRANCISCO GUERRA SANZ
}

From the Department of Pulmonary Medicine, Victoria Eugenia Hospital, Madrid, Spain

\begin{abstract}
Garcia de Cabo, A., Martinez Larriba, P. L., Checa Pinilla, J., and Guerra Sanz, F. (1978). Thorax, 33, 270-272. A new method of disinfection for the flexible fibrebronchoscope. A modified method for rapid sterilisation of the fibrebronchoscope using immersion of the instrument in $0 \cdot 1 \%$ benzalkonium chloride for five minutes followed by a further five minutes' immersion in $96 \%$ alcohol was tested both by deliberate contamination of rubber catheters and on bronchoscopes after use in patients. The method proved effective in eliminating a wide range of potentially pathogenic organisms.
\end{abstract}

For several years we have sterilised the flexible fibrebronchoscope using benzalkonium chloride, which has given excellent results. This cleansing agent has several advantages in addition to its antibacterial activity, as it is harmless to the materials used in the construction of the fibrebronchoscope, it is cheap and noncorrosive, and it does not stain. As Kato and Matsushima (1974) obtained unsatisfactory results using a similar technique we decided to test the antibacterial efficacy of our method.

\section{Methods}

VALIDATION OF THE ORIGINAL METHOD

The method we use for disinfection of the flexible fibrebronchoscope consists of initial rinsing of the instrument with normal saline and aspiration of $200 \mathrm{ml} 0.1 \%$ benzalkonium chloride solution through the internal lumen followed by a second rinse with normal saline. The exterior of the instrument is cleaned with gauze soaked in benzalkonium chloride and, after a further saline rinse, the instrument is air-dried. To test the efficacy of this method the following experiment was performed.

Two $50-\mathrm{cm}$ rubber catheters were immersed for five minutes in a culture of a mixture of microorganisms (Table 1) prepared in trypticase soy culture medium. One of the catheters was then immediately transferred to sterile culture medium while the second was cleaned and disinfected by the method regularly used for sterilisation of the flexible fibrebronchoscope, after which it, too, was placed in sterile culture medium. Colony counts were performed on the two plates after 24 hours' incubation at $37^{\circ} \mathrm{C}$.

INVESTIGATION OF EFFICACY OF A MODIFIED CLEANING PROCEDURE

The original method was modified by the addition of a second active agent, $96 \%$ alcohol. After initial rinsing of the exterior and lumen of the flexible fibrebronchoscope with normal saline the instrument was immersed in $0.1 \%$ benzalkonium chloride solution for not less than five minutes and a quantity was drawn through the length of the inner lumen by means of a syringe. The procedure was then repeated for five minutes using $96 \%$ alcohol and the instrument was air-dried.

The method was tested in two ways. Two rubber catheters were infected by a five-minute immersion in the trypticase soy culture medium described above; one was immediately placed in sterile culture medium, and the other was cleaned by the modified method described above before it, too, was placed in the culture medium. Both test and control plates were incubated for 24 hours at $37^{\circ} \mathrm{C}$.

After examination of a series of randomly chosen patients with the Olympus BF2 fibrebronchoscope, swabs were taken after each examination from the brush and external surfaces of the instrument and cultured on blood and chocolate agar plates. In addition, $5 \mathrm{ml}$ of sterile culture medium was injected down the inner 
lumen, collected under sterile conditions, and incubated at $37^{\circ} \mathrm{C}$ for 24 hours, after which it was cultured on blood and chocolate agar plates. Separate cultures for Mycobacterium tuberculosis and Aspergillus species were performed on Löwenstein-Jensen medium, read at two months, and on Sabouraud medium, read at 20 days. The fibrebronchoscope was then cleaned using the modified method and the cultures were repeated as before. All other plates were incubated for 24 hours, when the colonies were counted and identified.

\section{Results}

The results of the catheter tests are shown in Tables 1 and 2. Significant bacterial contamination after cleaning by the original method was encountered. This was eliminated by the modified method.

Specimens cultured from the fibrebronchoscope after 24 randomly selected examinations showed bacterial growth in all cases, although in only

Table 1 Culture of experimentally contaminated catheters with and without cleaning by original method

\begin{tabular}{llc}
\hline & $\begin{array}{l}\text { Colonies/ml } \\
\text { Untreated catheter }\end{array}$ & Treated catheter \\
\hline Microorganism & $>100000$ & 0 \\
\hline Escherichia & $>100000$ & 0 \\
Serratia marcescens & $>100000$ & 0 \\
Haemophilus influenzae & $>100000$ & 3000 \\
Staphylococcus aureus & $>100000$ & 0 \\
Pseudomonas aeruginosa & $>100000$ & 2000 \\
Proteus vulgaris & $>100000$ & 0 \\
Streptococcus pneumoniae & $>100000$ & 4000 \\
Klebsiella pneumoniae & & \\
\hline
\end{tabular}

Table 2 Culture of experimentally contaminated catheters, treated and untreated by modified method

\begin{tabular}{llll}
\hline $\begin{array}{lll}\text { No. of } \\
\text { Experiments }\end{array}$ & Microorganism & $\begin{array}{l}\text { Catheter } \\
\text { Untreated }\end{array}$ & Treated \\
\hline 3 & Aspergillus sp. & Growth & No growth \\
3 & Mycobacterium tuberculosis & Growth & No growth \\
6 & Streptococcus pneumoniae & Growth & No growth \\
4 & Pseudomonas aeruginosa & Growth & No growth \\
1 & Enterobacter cloacae & Growth & No growth \\
3 & Escherichia coli & Growth & No growth \\
4 & Klebsiella pneumoniae & Growth & No growth \\
4 & Haemophilus influenzae & Growth & No growth \\
1 & Providencia stuartii & Growth & No growth \\
1 & Serratia marcescens & Growth & No growth \\
3 & Proteus mirabilis & Growth & No growth \\
1 & Enterobacter aerogenes & Growth & No growth \\
1 & Proteus morganii & Growth & No growth \\
4 & Staphylococcus aureus & Growth & No growth \\
1 & Flavobacterium sp. & Growth & No growth \\
1 & Pseudomonas putrefaciens & Growth & No growth \\
1 & Citrobacter freundii & Growth & No growth \\
1 & Pseudomonas sp. & Growth & No growth \\
1 & Proteus vulgaris & Growth & No growth \\
44 & & & \\
\hline
\end{tabular}

eight instances were the infecting organisms potentially pathogenic (Table 3 ). After cleaning with the modified technique all cultures were negative, except for one which grew Staphylococcus epidermidis, thought to be a contaminant.

\section{Discussion}

Although we had used the original method for several years with satisfactory results, it was found to be deficient in circumstances where there was gross bacterial contamination. The modified technique, however, appears to be effective against the organisms used in the experiments, which are

Table 3 Culture of swabs taken from fibrebronchoscopes after use in 24 patients-before disinfection

\begin{tabular}{|c|c|c|c|}
\hline $\begin{array}{l}\text { No. of } \\
\text { patients }\end{array}$ & Channel & Surface & Brush \\
\hline $\begin{array}{l}1-4 \\
5\end{array}$ & $\begin{array}{l}\text { Saprophytes } \\
\text { Haemophilus influenzae }\end{array}$ & $\begin{array}{l}\text { Saprophytes } \\
\text { Haemophilus influenzae } \\
\text { Staphylococcus aureus }\end{array}$ & $\begin{array}{l}\text { Saprophytes } \\
\text { Haemophilus influenzae }\end{array}$ \\
\hline 6 & $\begin{array}{l}\text { Saprophytes } \\
\text { Haemophilus influenzae }\end{array}$ & Saprophytes & $\begin{array}{l}\text { Saprophytes } \\
\text { Haemophilus influenzae }\end{array}$ \\
\hline 7,8 & Saprophytes & Saprophytes & Saprophytes \\
\hline 9 & - & - & Mycobacterium tuberculosis \\
\hline 10 & Saprophytes & Saprophytes & Saprophytes \\
\hline 11 & $\begin{array}{l}\text { Staphylococcus aureus } \\
\text { Pseudomonas aeruginosa }\end{array}$ & $\begin{array}{l}\text { Staphylococcus aureus } \\
\text { Pseudomonas aeruginosa }\end{array}$ & Staphylococcus aureus \\
\hline $\begin{array}{l}12-17 \\
18\end{array}$ & Saprophytes & Saprophytes & Saprophytes \\
\hline 19 & - & $\begin{array}{l}\text { Saprophytes } \\
\text { Saprophytes }\end{array}$ & Saprophytes \\
\hline $\begin{array}{l}20 \\
21\end{array}$ & $\begin{array}{l}\text { Saprophytes } \\
\text { Escherichia coli }\end{array}$ & $\begin{array}{l}\text { Saprophytes } \\
\text { Escherichia coli } \\
\text { Saprophytes }\end{array}$ & $\begin{array}{l}\text { Streptococcus pneumoniae } \\
\text { Escherichia coli } \\
\text { Saprophytes }\end{array}$ \\
\hline 22 & Saprophytes & $\begin{array}{l}\text { Saprophytes } \\
\text { Staphylococcus aureus }\end{array}$ & $\begin{array}{l}\text { Saprophytes } \\
\text { Staphylococcus aureus }\end{array}$ \\
\hline $\begin{array}{l}23 \\
24\end{array}$ & $\begin{array}{l}\text { Pseudomonas aeruginosa } \\
\text { Saprophytes } \\
\text { Saprophytes }\end{array}$ & $\begin{array}{l}\text { Saprophytes } \\
\text { Saprophytes }\end{array}$ & $\begin{array}{l}\text { Pseudomonas aeruginosa } \\
\text { Saprophytes } \\
\text { Saprophytes }\end{array}$ \\
\hline
\end{tabular}


commonly encountered in practice, even though they were present in concentrations not normally found in the bronchial tree.

Although cross-infection as a result of fibrebronchoscopy is not a common occurrence, whatever the method of sterilisation used, clearly an effective method should be employed. None can be considered reliable unless tested under conditions of maximal bacterial contamination, and the modified technique we propose of $0.1 \%$ benzalkonium chloride and $96 \%$ alcohol rinsing appears to fulfil the requirements of an effective, rapid, and non-toxic cleaning procedure.

\section{Reference}

Kato, H., and Matsushima, S. (1974). Experimental study for rapid sterilisation of the flexible fiberoptic bronchoscope. Chest, 66, 723-724.

Requests for reprints to $\operatorname{Dr}$ A. Garcia de Cabo, Hospital de Enfermedades del Torax, Victoria Eugenia, Sinesio Delgado 8, Madrid 29, Spain. 